\title{
WACANA KRITIS FAIRCLOUGH DALAM TEKS IKLAN MANA TAU: INDIAN ROYAL COFEE
}

\author{
Khikmah Susanti* \\ Universitas Indraprasta PGRI \\ Puji Anto \\ Universitas Indraprasta PGRI \\ Atiek Nur Hidayati \\ Universitas Indraprasta PGRI \\ Kampus A Jl. Nangka No.58C Tanjung Barat (TB Simatupang), Jagakarsa, Jakarta Selatan, 12530, Indonesia; \\ e-mail: antopujifafafa@gmail.com
}

\begin{abstract}
Tujuan dalam penelitian ini adalah untuk mengungkap idiologi dan tujuan dari pengiklan. Motode analisis yang digunakan dalam analisis ini yaitu menggunakan model analisis wacana kritis Norman Fairclough yang melihat teks (iklan) berdasarkan tiga dimensi, yaitu teks (teks), praktik teks (discourse practice) dan praktik sosiokultural (sociocultural practice). Hasil penelitian berdasarkan analisis kebahasaan pada iklan banyak menggunakan identitas-identitas tertentu, seperti identitas milenials dan India. Milenials diwakili dengan kata komiters, gue, letsgo, sedangkan India diwakili dengan kata "aca-aca" dan "tekstur" untuk menggambarkan makanan India yang lain daripada yang lain. Eufimisme juga mucul ketika iklan menggunakan kata "kita" yang menunjukkan kesejajaran antara pengiklan dan pembaca. Tidak menunjukkan otoritasnya sebagai pengiklan. Berdasarkan analisis praktik teks dari sisi produksi dan konsumsi, pengiklan tahu betul kebutuhan para penumpang KRL, khususnya Masyarakat Bogor dengan kebiasaan cuaca dingin sehingga disuguhkan makanan yang pedas untuk menghangat suhu tubuh. Sasaran pengiklan pun sangat jelas yaitu kaum milenials. Pengiklan menyampaikan pesan dengan sangat sederhana dan informal serta diperkuat dengan penggunaan aksesoris ciri khas negara asal makanan tersebut. Berdasarkan analisis praktik sosiokultural, pengiklan sudah mengidentifikasi pola hidup masyarakat Indonesia saat ini, yaitu konsumtif dan modernitas sehingga disuguhkan pilihan makanan yang menunjukkan kelas tertentu. Faktor kebahagiaan dalam menjalani hidup juga ditawarkan dalam iklan. Menghibur diri tidak hanya sekadar berwisata di tempat-tempat yang indah, tetapi dapat juga dilakukan dengan mencoba berbagai macam jenis makanan dari berbagai negara. Pengiklan mengarah pada sebuah institusi tertentu, yaitu kalangan kelas menengah, tetapi memunculkan kesan kelas atas. Gaya hidup konsumtif menjadi dasar pengiklan untuk menyuguhkan jenis makanan yang lain dari biasanya.
\end{abstract}

Keywords: Wacana Kritis Fairclough, iklan.

Article History: Received: 22/19/2019; Revised: 25/10/2019; Accepted: 20/11/2019; Published: 31/12/2019

How to Cite (MLA 7th): Khikmah Susanti, Puji Anto, Atiek Nur Hidayati . “Wacana Kritis Fairclough dalam teks Iklan Mana Tau: Indian Royal Cofee ." Hortatori Jurnal Pendidikan Bahasa dan Sastra Indonesia vol3 no2 (2019): 111-117. Print/Online. Copyrights Holder: Khikmah Susanti, Puji Anto, Atiek Nur Hiday. First Publication: Hortatori Jurnal Pendidikan Bahasa dan Sastra Indonesia (2019)

This work is licensed under a Creative Commons Attribution-ShareAlike 4.0 International License.

\section{Pendahuluan}

Analisis kritis sebagai pisau adalah sebuah upaya atau proses (penguraian) untuk memberi penjelasan dari sebuah teks (realitas sosial) yang mau atau sedang dikaji oleh seseorang atau kelompok yang kecenderungannya mempunyai tujuan tertentu untuk memperoleh apa yang 
diinginkan. Dalam sebuah konteks juga harus disadari akan adanya kepentingan dan ideologi yang ingin disampaikan. Oleh karena itu, analisis yang terbentuk nantinya disadari telah dipengaruhi oleh si penulis dari berbagai faktor, dapat dikatakan bahwa, di balik wacana itu terdapat makna dan citra yang diinginkan serta kepentingan yang sedang diperjuangkan.

Wacana adalah proses pengembangan dari komunikasi yang menggunakan simbol-simbol, berkaitan dengan interpretasi dan peristiwa-peristiwa di dalam sistem kemasyarakatan yang luas. Melalui pendekatan wacana, pesan-pesan komunikasi, seperti kata-kata, tulisan, gambar-gambar, dan lain-lain, eksistensinya ditentukan oleh orang-orang yang menggunakannya, konteks peristiwa yang berkenaan dengannya, situasi masyarakat luas yang melatarbelakangi keberadaannya, dan lain-lain. Kesemuanya itu dapat berupa nilai-nilai, ideologi, emosi, kepentingan-kepentingan, dan lain-lain.

Iklan merupakan salah satu yang sering digunakan oleh seseorang atau kelompok untuk mempromosikan suatu barang, jasa, atau yang lainnya. Penggunaan bahasa dalam iklan sering bersifat persuasif yang bertujuan untuk memberikan pengaruh, ajakan, dan memberikan keyakinan pada khalayak tentang sesuatu atau kegiatan.

Iklan atau pariwara adalah promosi benda, seperti barang, jasa, tempat usaha, dan ide yang harus dibayar oleh sebuah sponsor. Manajemen pemasaran melihat iklan sebagai bagian dari strategi promosi secara keseluruhan. Komponen lainnya dari promosi termasuk publisitas, hubungan masyarakat, penjualan, dan promosi penjualan.

Dalam produksi iklan, seseorang membuat iklan tidak disusun begitu saja, tetapi perlu melihat sosiokultural yang ada sehingga nantinya barang atau jasa yang ditawarkan bisa diterima. Dengan memahami sosiokutural suatu masyarakat (sebagai tujuan) akan mengantarkan iklan tersebut pada penerimaan yang utuh dan berimplikasi pada konsumsi produk atau jasa. Tujuan besar dari pembuatan iklan adalah agar pembaca atau khalayak terpengaruh dan tertarik untuk menikmati produk atau jasa yang ditawarkan.

Berdasarkan hal tersebut, iklan tidak lepas dari ideologi yang ingin disampaikan oleh pembuat iklan (melalui perumusan dan penyusunan kata dan kalimat). Melalui pemahaman ideologi, seseorang dapat memahami apa tujuan yang mendasari pengomunikasian iklan tersebut melalui medium bahasa yang digunakan. Analisis dalam penelitian ini dofokuskan pada iklan Indian Royal Café. Hal itu berdasarkan survei yang dilakukan terhadap beberapa penumpang komuter line. Dari beberapa iklan yang ada, penumpang banyak yang suka dengan iklan Indian Royal Café dengan berbagai alasan, salah satu alasan yang paling menonjol adalah terkait dengan kebutuhan perut, yaitu makanan. Adanya makanan dari negara lain dapat dijadikan pengalaman lidah dalam proses mengunyah. Judul iklan tersebut adalah "Mana tau: Indian Royal Café. Iklan ini ditayangkah dalam DOOH (Digital-Out-Of-Home) suatu fasilitas dalam Kereta Rel Listrik (KRL).

Model analisis wacana kritis yang digunakan dalam analisis iklan tersebut adalah model wacana kritis Norman Fairclough yang melihat wacana/teks (iklan) dari tiga dimensi, yaitu teks, praktik teks, dan praktik sosiokultural. Dari analaisis ini diharapkan akan ditemukan ideologi dan tujuan yang ingin disampaikan oleh pembuat iklan melalui medium bahasa yang digunakan.

\section{Metode}

Motode analisis yang digunakan dalam analisis ini yaitu menggunakan model analisis wacana kritis Norman Fairclough yang melihat teks (iklan) berdasarkan tiga dimensi yaitu teks (teks), praktik teks (discourse practice) dan praktik sosiokultural (sociocultural practice).

Analisis Wacana kritis Norman Fairclough didsarkan pada pertanyaan besar, bagaimana menghubungkan teks yang mikro dengan konteks masyarakat yang makro. Fairclough berusaha membangun suatu model analisis wacana yang mempunyai kontribusi dalam analisis sosial dan budaya, sehingga ia mengombinasikan tradisi analisis tekstual yang selalu melihat bahasa dari dalam ruang tertutup dengan konteks masyarakat yang lebih luas. Menurut Eryanto (2001:285) Titik perhatian besar Fairclough adalah melihat bahasa sebagai praktik kekuasaan. Dapat dikatakan bahwa, analisis wacana kritis Fairclough merupakan analisis wacana yang paling lengkap dalam mengungkap ideologi yang terkandung dalam teks. Makna yang terkandung dilihat dari tiga dimensi mulai dari teks, produksi teks, dan sosiokultural yang membangun teks tersebut.

Pendekatan Fairclough intinya menyatakan bahwa, wacana merupakan bentuk penting praktik 
sosial yang memproduksi dan mengubah pengetahuan, identitas, dan hubungan sosial yang mencakup hubungan kekuasaan dan sekaligus dibentuk oleh struktur dan praktik sosial yang lain (Jorgensen dan Philips, 2010:122-123). Oleh sebab itu, dalam tatanan diskursus Fairclough, wacana memiliki hubungan dialektik dengan dimensi-dimensi sosial yang lain. Artinya wacana dibangun bukan hanya dari bahasa saja tetapi wacana dibangun berdasarkan tatanan sosial atau prakteks sosial yang ada yang refleksikan melalui medium bahasa (linguistik).

Faiclough memahami struktur sosial sebagai hubungan sosial di masyarakat secara keseluruhan dan di lembaga-lembaga khusus yang terdiri atas unsur-unsur kewacanaan dan non kewacanaan. Yang dimaksud dengan kewacanaan dan non kewacanaan adalah bahasa (wacana) dan nonkewacanaan (masyarkat). Menurut Fairclough (2003:25) tidak ada hubungan eksternal antara bahasa dan masyarakat, namun pada hubungan internal dan dialektikal. Bahasa adalah bagian dari masyarakat, fenomena linguistik adalah fenomena sosial yang khusus, dan fenomena sosial adalah sebagai fenomena linguistik.

Bahasa sebagai praktik sosial, meanampakkan hubungan yang sangat erat antara fenomena linguistik dengan tatanan sosial yang ada. Fenomena linguistik bersifat sosial yang dimanapun orang berbicara, mendengar, menulis, dan membaca, mereka melakukan dengan cara-cara yang tergantung pada kondisi sosial dan juga mempunyai efek sosial (Fairclough, 2003:25).

Menurut Eryanto (2001:285) Norman Fairclough membangun sebuah model yang mengintegrasikan secara bersama-sama analisis wacana yang didasarkan pada linguistik dan pemikiran sosial dan politik, dan secara umum diintegrasikan pada perubahan sosial. Oleh sebab itu, dapat dikatakan bahwa, model Fairclough sebagai model perubahan sosial.

Pemusatan Fairclough pada bahasa sebagi praktik sosial, lebih daripada aktivitas individu untuk merefleksikan sesuatu. Menurut Eryanto (2001:286) dalam hal ini mengandung sejumlah implikasi yaitu; 1) wacana adalah bentuk dari tindakan, seseorang menggunakan bahasa sebagai suatu tindakan pada dunia dan khususnya sebagai bentuk perepresentasi ketika melihat duania/realitas, 2) adanya hubungan timbal balik antara wacana dengan struktur sosial, kelas, dan relasi sosial lain yang dihubungkan dengan relasi spesifik dari institusi tertentu.

Fairclough membagi analisis wacana dalam tiga dimensi yaitu teks, discourse practice dan sociocultural practice. Dalam model Fairclough, teks dianalisis secara linguistik, dengan melihat kosakata, kalimat dan semantik. Disamping itu juga, ia juga memperhatikan kohesifitas dan koherensi, bagaimana antarkata atau kalimat tersebut digabung sehingga membentuk pengertian. Semua elemen yang dianalisis tersebut dipakai untuk melihat tiga masalah berikut yaitu; a) ideasional yang merujuk pada representasi tertentu yang ingin ditampilkan dalam teks, yang umumnya membawa muatan ideologi tertentu. Analisis ini pada dasarnya melihat sesuatu yang ditampilkan dalam teks bisa jadi membawa muatan ideologis terntentu, b) relasi, merujuk pada analis konstruksi hubungan antara wartawan dengan pembaca, seperti apakah teks disampaikan secara formal dan informal, terbuka atau tertutup, dan yang terakhir c) identitas, merujuk pada kontruksi tertentu dari identitas wartawan dan pembaca, serta bagaimana personal dan identitas ini hendak ditampilkan (Eryanto, 2001:286-287).

Doscourse practice merupakan dimensi yang berhubungan dengan proses produksi dan konsumsi teks (Eryanto, 2001:287). Sebuah teks berita pada dasarnya dihasilkan lewat produksi teks yang berbeda, seperti bagaimana pola kerja, bagan kerja, dan rutinitas dalam menghasilkan berita. Sering kali ditemukan adanya perbedaan cara menyampaikan atau produksi berita oleh wartawan, karena hal ini dipengaruhi oleh media yang satu mungkin sekali mempunyai pola kerja dan kebiasaan yang berbeda dibandingkan dengan media lain.

Adapun sociocultural practice adalah dimensi yang berhubungan dengan konteks di luar teks (Eryanto, 2001:288). Pada konteks ini banyak memasukkan hal lain seperti, konteks situasi, lebih luas adalah konteks dari praktik institusi dari media sendiri dalam hubugannya dengan masyarakat atau budaya dan politik tertentu. Misalnya politik media, budaya media atau ekonomi media tertentu yang berpengaruh terhadap berita yang dihasilkannya. 


\section{Hasil dan Diskusi}

Berikut hasil analisis iklan "Mana tau: Indian Royal Café" yang diambil dari situs https://macroad.com/krl/ (MacroAd.com, 2019) berdasarkan model analisis wacana kritis yang ditawarkan oleh Norman Fairclough, mulai dari (1) analisis teks, (2) praktik teks, dan (3) praktik sosiokultural.

\section{Analisis Teks}

\section{Representasi (mewakili)}

Analisis yang pertama pada tahap analisis teks adalah dengan menampilkan makna yang direpresentasikan di dalam iklan. Representasi terlihat dari pilihan kata yang digunakan secara monolog dengan memunculkan kata "Gue". Kata "Gue" merupakan persona pertama tunggal yang diambil dari bahasa Betawi, dalam Bahasa Indonesia bermakna 'saya'. Hal itu menunjukkan bahwa iklan menyasar pada generasi muda atau melenials yang sering menggunakan kata "Gue" dalam percakapan kesehariaanya. Ternyata, kata "Gue" tidak hanya dipakai oleh orang Betawi saja, tetapi meluas ke daerah yang lain. "Gue" sekarang ini tidak sebatas kedaerahan, tetapi masuk ke ranah generasi yang bersifat kemudaan atau milenials. Kata ganti orang kedua juga digunakan dalam iklan ini, yaitu kata "komiters". Penggunaan kata "komiters' ingin mewakili penumpang kerata atau KRL karena iklan ini ditayangkan dalam DOOH (Digital-Out-Of-Home) yang terpasang di dalamnya. Penggunaan kata komiters untuk mewakili para penumpang ingin menunjukkan keakraban atau bersifat informal. Iklan tersebut juga menggunakan kata "kita", persona pertama jamak. Dengan begitu, iklan tersebut bermaksud untuk melibatkan dirinya sendiri dan masyarakat, khususnya penumpang KRL, lebih khusus lagi untuk penumpang KRL yang tujuan akhirnya adalah Stasiun Bogor. Hal itu menunjukkan suatu sikap interpersonal.

Iklan "Indian Royal Café" juga ingin menyugesti masyarakat, yaitu mencoba mengaitkan suasana adem (Dingin) dengan laper (Lapar). Hal itu tergambar pada kalimat berikut: “..., tapi hawanya adem-adem gimana gituh komiters, bikin laper gitu" .... Kalimat tersebut sering muncul di masyarakat yang bersifat sugesti. Pada dasarnya tidak ada keterkaitan antara kata dingin dan lapar kalau dilihat dari arti katanya. Kata dingin dalam Kamus Besar Bahasa Indonesia Daring adalah bersuhu rendah apabila dibandingkan dengan suhu tubuh manusia; tidak panas; sejuk, sedangkan kata lapar adalah berasa ingin makan (karena perut kosong) (kbbi.kemdikbud.go.id).

Penggunaan kalimat "Indian Royal Café ... ini pasti makan khas indiahe-indiahe aca- aca nih komiters" merupakan perwakilan kelembagaan. Makna yang jelas tampak bahwa apa yang tersedia adalah jenis makanan khas India. Iklan tersebut juga menggunakan identitas yang sering muncul jika bersinggungan dengan keindiaan, seperti kata "aca-aca".

Ada sebuah identitas yang dibangun dalam iklan tersebut, yang mewakili identitas dari makanan khas India, yaitu munculnya kata "tekstur".

Pertama gue mau makan Indian ciken kari bus mati pulau rich, lihai nih bentuk nasinya beda dari nasi yang biasa yang kita makan, teksturnya kering, tapi gak keras komiters ... ciken karinya juga berasa banget rempah-rempahnya nyam ... menu selanjutnya Indian muton kari parata, muton itu daging kambing komiters dan yang ini rasa karinya lebih pedes tapi perpaduan sama paratanya ternyata lebih enak loh, kalua tadi gue makan parata pakai pari, sekarang gue makannya pakai ice cream ... hem mini enak komiters dan tekstur paratanya juga lebih tipis, rata, dan manis ...

Makna kata tekstur dalam teks iklan tersebut adalah sebuah identitas makanan India yang menjadi pembeda dengan Indonesia. Jenis makanan yang dimaksud adalah nasi India dan parata "sejenis roti" dari India. Nasi India butiran nasinya lebih besar ukurannya, teksturnya kering, tatapi tidak keras, sedangkan di Indonesia butiran berasnya lebih kecil. Paratanya juga mempunyai tekstur yang yang lebih tipis, sejenis roti yang beda dari biasanya. Biasanya roti di Indonesia berukuran tebal.

\section{Relasi (hubungan)}

Iklan "Indian Royal Café" secara relasi atau hubungan dilihat dari diksi yang digunakan ingin mengesankan keakaraban. Keakraban tergambar pada penggunaan kata yang bersifat informal atau kekeluargaan, seakan-akan antara pengiklan dan masyarakat hubungannya sangat dekat. Hal itu tergambar pada penggunaan kata ganti orang, seperti "komiters", "gue", dan "kita", serta kata yang lainnya, seperti kata "adem", "laper", "gituh", "tapi", "filing", "letsgo". Penggunaan kata berbahasa Inggris dicampur dengan Bahasa Indonesia saat ini sangat marak terutama generasi melenials yang 
sering disebut dengan bahasa "jaksel". Penggunaan bahasa dilihat secara relasi cenderung bersifat terbuka, hal itu terlihat pada penggunaan kata yang tidak baku, semakin akrab situasi percakapan, maka bahasa yang muncul ketidakbakuan.

\section{Identitas}

Identitas yang coba dibangun dalam iklan tersebut adalah kesetaraan antara orang Indonesia dan India. Hal itu ditunjukan dengan penggunaan kata "kita". Dapat diartikan bahwa selera makanannya sama, sehingga makanan khas India dapat dinikmati oleh orang Indonesia tanpa merasakan hal yang aneh setiap makan makanan khas India. Hal itu berbeda jika orang Indonesia disuguhkan dengan makanan yang berasalah dari Eropa. Kata "aca-aca" juga mewakili identitas yang sangat kuat pada India. Hal itu dapat menjadi relevan karena banyak film-film India yang sering ditayangkan di televesi dan kata tersebut sering muncul sehingga familier keindianya.

Berdasarkan analisis kebahasaan pada iklan banyak menggunakan identitas-identitas tertentu, seperti identitas milenials dan India. Milenials diwakili dengan kata komiters, gue, letsgo, sedangkan India diwakili dengan kata "aca-aca" dan "tekstur" untuk menggambarkan makanan India yang lain daripada yang lain. Eufimisme juga mucul ketika iklan menggunakan kata "kita" yang menunjukkan kesejajaran antara pengiklan dan pembaca. Tidak menunjukkan otoritasnya sebagai pengiklan.

\section{Praktik Teks \\ Produksi}

Dilihat secara produksi, si pembuat iklan sangat menyadari penumpang KRL yang berhenti di Stasiun Bogor. Oleh sebab itu, Indian Royal Café sangat tepat diiklankan di KRL. Menu India yang ditawarkan bercita rasa pedas, hal itu sangat cocok dengan cuaca dingin yang identik dengan kota Bogor (Kota Hujan). Menu pedas dapat menghangatkan badan disaat cuaca dingin. Pengiklan juga tahu betul bahwa mayoritas penumpang KRL adalah kalangan milenials. Oleh karena itu, pengiklan menggunakan identitas kemelenialsan, seperti kata "Gue", "Komuters", dan kata-kata yang tidak baku atau informal.

\section{Konsumsi}

Kebutuhan akan suasana yang ramah dengan tubuh, seperti dingin, akan mudah menarik perhatian orang. Dengan penyampean yang sangat sederhana dan tidak terkesan muluk-muluk akan mudah dipahami dan tidak membutuhkan cara berpikir yang berat. Saat ini masyarakat lebih mudah menerima hal-hal yang sederhana. Hal-hal yang bersifat muluk-muluk atau berlebihan akan terkesan tidak apa adanya. Konsep eufimisme juga masih digunakan serta terkesan alamiah.

Dengan menampilkan latar salah satu sudut kota Bogor dan penampakan café-nya, maka terjalin adanya kedekatan. Penampakan beberapa perangkat yang digunakan dalam café juga mengisyaratkan memenuhi kebutuhan dari kaum milenials. Tidak kalah penting, adanya penggunaan aksesoris yang digunakan oleh tokoh pada iklan juga sebagai petanda yang kuat apa yang menjadi jualan café tersebut.

Berdasarkan analisis praktik teks dari sisi produksi dan konsumsi, pengiklan tahu betul kebutuhan para penumpang KRL, khususnya masyarakat Bogor dengan kebiasaan cuaca dingin sehingga disuguhkan makanan yang pedas untuk menghangat suhu tubuh. Sasaran pengiklan pun sangat jelas yaitu kaum milenials. Pengiklan menyampaikan pesan dengan sangat sederhana dan informal serta diperkuat dengan penggunaan aksesoris ciri khas negara asal makanan tersebut.

\section{Praktik Sosiokultural}

Iklan ini mengarah pada promosi bisnis. Penyebaran wacana promosi pada tataran wacana merupakan daya dorong dalam perkembangan kemasyarakatan yang lebih luas dan moderen. Masyarakat pada umumnya sekarang dihadapkan pada kebutuhan moderenititas yang dapat menunjang kebutuhan hidup yang lebih praktis dan instan. Tuntutan moderenitas ini memberikan kemudahan pada akses-askses yang lebih dalam mencapai kebutuhan yang sesuai dengan harapan. Terutama pada hal yang ada kaitannya kebutuhan primer (makan) ataupun gaya hidup demi melampiaskan kepenatan akibat rutinitas yang monoton dan cenderung tidak menyenagkan.

Masyarakat sekarang ini dihadapkan pada modernitas yang tinggi untuk bersaing dalam mencapai hidup lebih baik dan mumpuni. Tidak jarang orang menginformasikan atau mempromosikan suatu produak dengan mengambinghitamkan sesuatu daripada memberikan fakta yang ada dan alamiah.

Penggunaan fakta dalam produksi iklan menjadi penyalur ideologi yang sangat pas

digunakan. Anggapan bahwa iklan berbicara apa adanya, sederhana, informal, dan sesuai fakta akan menjadi alasan untuk menerima dengan cepat apa yang disampaikan. Untuk menjelaskan proses sosial 
yang lebih luas itu, juga mencakup daya nonkewacanaan, Fairclough menggunakan moderinitas akhir. Iklan tersebut menampakkan moderinitas akhir yaitu bagaimana mayarakat dihadapkan pada informasi dan teknologi terkini yang bisa menunjang kehidupan yang lebih berfariatif atau tidak monoton sehingga hidup menyenaangkan. Identitas dan hubungan sosial masyarakat tidak lagi disasarkan pada posisi sosial yang stabil, tetapi agaknya diciptakan melalui negosiasi-negosiasi dalam interaksi keseharian (Gildens dalam Jorgensen dan Philips, 2007:156). Ini menunjukkan bahwa, iklan mendapat peran penting dalam negosiasi-negosiasi, baik itu dalam produksi dan jasa, seperti iklan tersebut yang memiliki negosiasi-negosiasi menawarkan sebuah inovasi terhadap jaminan hidup yang berfariatif, yaitu makanan yang termasuk dalam gaya hidup.

Situasional

Situasional yang digambarkan dalam iklan tersebut adalah situasional moderenitas yang mengedepankan gaya hidup kelas atas. Kedua iklan tersebut diproduksi berdasarkan konteks sosial yang ada saat ini, selalu mengedepankan kebutuhan-kebutuhan yang lebih baik untuk kehidupan, seperti kebutuhan perut dan kebahagiaan. Dilihat dari situasional yang ada, teks diproduksi berdasarkan suatu kondisi yang khas dan unik. Hal tersebut terbukti pada iklan yang dibicarakan. Iklan tersebut mengsung tema tentang makanan, yaitu makan khas India sebagai alternatif mengisi perut kosong dalam cuaca yang dingin dengan menu bernuansa pedas atau ada kari-karinya. Situasi ini akan memberikan hal yang berbeda dari biasanya. Biasanya hal yang berbeda akan memberikan kesan kepuasan dan kebahagiaan. Hal itu sangat erat kaitannya keberlangsungan dalam menikmati hidup yang diakui atau tidak diakui selalu ada munculnya masalah dalam hidup dan harus mampu menyelesaikanya dengan baik agar hidup berjalan dengan lancar.

\section{Institusional}

Secara institusional, teks diproduksi dengan melihat faktor khalayak sebagai faktor konsumsi berdasarkan faktor ekonomi dan budaya. Misalnya, faktor ekonomi, dalam iklan menyinggung harga makanan yang terjangkau "Indian Royal Café Bogor menyediakan makanan khas India dengan rasa yang lezat dan harga yang terjangkau." Hal itu menunjukkan institusional mana yang disasar oleh iklan. Faktor sosial, iklan memberikan tawaran kebudayaan yang lain, yaitu kebudayaan India, khususnya terkait ciri khas makanan. Hal itu mengisyaratkan bahwa kebudayaan India juga dapat diterima di Indonesia selain kebudayaan negara lain yang sudah menjamur di Indonesia. Pengiklan menyuguhkan beberapa jenis makanan yang cocok dengan kondisi lingkungan di Indonesia, khususnya Kota Bogor dengan cuaca dinginnya.

\section{Sosial}

Dilihat dari kodisi sosial yang ada di Indonesia, masyarakat Indonesia lebih mengarah pada gaya hidup tinggi dan konsumtif. Masyarakat Indonesia selalu tergiur dengan produk-produk baru. Gaya hidup selalu berkaitan dengan sesuatu hal yang baru sehingga para pembisnis selalu menyuguhkan sesuatu yang baru dari negara lain. Menyuguhkan sesuatu yang baru, terkait makanan, sudah menjadi tradisi di Indonesia, bahkan beberapa jenis makanan dari luar laris manis di Indonesia mengalahkan makanan khas tradisionalnya sendiri. Misi iklan sangat jelas, mempromosikan kebudayaan negara lain supaya berkembang di Indonesia, hal itu berdasar pada tren masyarakat Indonesia yang konsumtif.

Berdasarkan analisis praktik sosiokultural, pengiklan sudah mengidentifikasi pola hidup masyarakat Indonesia saat ini, yaitu konsumtif dan modernitas sehingga disuguhkan pilihan makanan yang menunjukkan kelas tertentu. Faktor kebahagiaan dalam menjalani hidup juga ditawarkan dalam iklan. Menghibur diri tidak hanya sekadar berwisata di tempat-tempat yang

indah, tetapi dapat juga dilakukan dengan mencoba berbagai macam jenis makanan dari berbagai negara. Pengiklan mengarah pada sebuah institusi tertentu, yaitu kalangan kelas menengah, tetapi memunculkan kesan kelas atas. Gaya hidup konsumtif menjadi dasar pengiklan untuk menyuguhkan jenis makanan yang lain dari biasanya.

\section{Simpulan}

Berdasarkan hasil analisis dari iklan yang berjudul "Mana Tau: Indian Royal Café" dapat disipulkan sebagai berikut.

1. Analisis Teks, berdasarkan analisis kebahasaan pada iklan banyak menggunakan identitas-identitas tertentu, seperti identitas milenials dan India. Milenials diwakili dengan kata komiters, gue, letsgo, sedangkan India diwakili dengan kata "aca-aca" dan "tekstur" untuk menggambarkan makanan India 
yang lain daripada yang lain. Eufimisme juga mucul ketika iklan menggunakan kata "kita" yang menunjukkan kesejajaran antara pengiklan dan pembaca. Tidak menunjukkan otoritasnya sebagai pengiklan.

2. Analisis praktik teks, berdasarkan analisis praktik teks dari sisi produksi dan konsumsi, pengiklan tahu betul kebutuhan para penumpang KRL, khususnya Masyarakat Bogor dengan kebiasaan cuaca dingin sehingga disuguhkan makanan yang pedas untuk menghangat suhu tubuh. Sasaran pengiklan pun sangat jelas yaitu kaum milenials. Pengiklan menyampaikan pesan dengan sangat sederhana dan informal serta diperkuat dengan penggunaan aksesoris ciri khas negara asal makanan tersebut..

3. Analisis prakstik sosiokultural, berdasarkan analisis praktik sosiokultural, pengiklan sudah mengidentifikasi pola hidup masyarakat Indonesia saat ini, yaitu konsumtif dan modernitas sehingga disuguhkan pilihan makanan yang menunjukkan kelas tertentu. Faktor kebahagiaan dalam menjalani hidup juga ditawarkan dalam iklan. Menghibur diri tidak hanya sekadar berwisata di tempat-tempat yang indah, tetapi dapat juga dilakukan dengan mencoba berbagai macam jenis makanan dari berbagai negara. Pengiklan mengarah pada sebuah institusi tertentu, yaitu kalangan kelas menengah, tetapi memunculkan kesan kelas atas. Gaya hidup konsumtif menjadi dasar pengiklan untuk menyuguhkan jenis makanan yang lain dari biasanya.

\section{Ucapan Terima Kasih}

Terima kasih kami ucapkan pada tim penulis yang mampu bekerja sama dengan baik. Kepada Lembaga Penelitian dan Pengabdian kepada Masyarakat Universitas Indraprasta PGRI yang telah memberikan kesempatan untuk melakukan penelitian secara mandiri yang mendasari dibuatnya artikel ilmiah ini, kami ucapkan terim kasih. Tidak lupa, terima kasi kami ucapkan kepada Program Studi Desain Komunikasi Visual, termasuk di dalamnya Kaprodi, Sesprodi, beserta Staf yang sudah mendukung secara administrative sehingga penelitian dapat diajukan dan disetujui untuk dilakukan secara mandiri.

\section{Daftar Rujukan}

Eriyanto. (2001). Analisis wacana pengantar teks media. Yokyakarta: LkiS Yogyakart.

Fairclough, N. (1989). Language and power; Relasi bahasa, kekuasaan, dan ideologi. Terjemahan Indah Rohmani-Komunitas Ambarawa. (2003). Malang: Boyan Publishing.

Jorgensen, M. W. \& Phillips, L. J. (Tanpa Tahun). Analisis wacana teori dan metode. Terjemahan Imam Suyitno dkk. (2010). Yogyakarta: Pustaka Pelajar.

Kamus Besar Bahasa Indonesia. (2019). https://kbbi.kemdikbud.go.id/entri/Dingin

Kamus Besar Bahasa Indonesia. (2019). https://kbbi.kemdikbud.go.id/entri/Lapar

MacroAd.com. (2019). Mana tau: Indian Royal Café. https://macroAd.com/krl/ 